\title{
The Advantages and Barriers of Establishing Sino Russian Free Trade Area from the Perspective of "The Belt and Road" Initiative
}

\author{
Yi-Jun XIANG ${ }^{1 a}$, Xue-Yao HAN ${ }^{2 b}$ \\ ${ }^{1}$ Harbin University of Commerce, Heilongjiang, China \\ ${ }^{2}$ Harbin University of Commerce, Heilongjiang, China \\ axyj6060@126.com, bhanxueyao93@126.com
}

Keywords: Sino Russian free trade area; "The belt and road" initiative; Regional economic integration

\begin{abstract}
With the trend of economic globalization and regional economic integration becoming the trend of world economic development, the economic and trade cooperation between countries has been deepening. China and Russia are linked with each other in land. Political stability, the economic structure is complementary to each other. With "The Belt and Road" initiative strategy continues to advance, the construction of Sino Russian free trade area has new opportunities. However, the Sino Russian economic and trade relations is not impeccable, for a long time, China and Russia's commercial property and trade system and policies have many drawbacks, the construction process of the bilateral free trade area of the obstacle is heavy, facing many difficulties.
\end{abstract}

\section{Introduction}

As the members of the BRICs, China and Russia play the important role in the development of the world economy. China is the largest trading country in the world and is the largest trading partner of Russia. Under the background world of economic globalization and regional economic integration, promoting the construction of Sino Russian free trade area, is embody equality and mutual trust, mutual support, and is also important to improve the strategic partnership between China and Russian. The economic cooperation between China and Russia has broad prospects for development, in the development and improvement of "The Belt and Road" initiative strategy, the construction of Sino Russian free trade area of the process toward a better direction.

\section{Favorable Factors for Establishing Sino Russian Free Trade Area}

\section{The Two Countries Border on Each Other.}

China and Russia has a more than $4300 \mathrm{~km}$ long land border which area is vast, the border area distribution of highway and railway and port, greatly promoting the development of border trade, it is very advantageous geographical conditions. Relying on the unique advantages of border trade between China and Russia has a history of 300 years, from scattered spontaneous petty trade gradually to the scale of development, the mode of trade has also developed from simplification to diversification In 1999, after China and Russia signed the relevant agreement on the establishment of the free trade area, establishing the border trade district successively in more than one city in China and Russian's border district. the Manchuria and Suifenhe mainly export of raw materials and mineral and other primary products to Russia; Heihe and Blagoveshchensk separated by a river, mainly export a lot of supplies to Russia, is the center of the development of border trade between the two countries, known as the "twin cities". The border trade between China and Russia has developed vigorously under the unique geographical environment. It has created a favorable prerequisite for further cooperation between China and Russia and the establishment of bilateral free trade area. 


\section{"The Belt and Road" Initiative Strategy Provides Opportunities for the Construction of the Sino Russian Free Trade Area.}

In September 7, 2013, Chinese President Xi Jinping made a speech in Kazakhstan and proposed the idea of building a "Silk Road Economic Belt". In March 28, 2015, the national development and Reform Commission, the Ministry of foreign affairs and the Ministry of Commerce issued the "vision and action to promote the construction of the Silk Road Economic Belt and the maritime Silk Road in twenty-first Century" jointly. In May 14, 2017, Belt and Road Forum for International Cooperation held in Beijing, the forum proposed to promote economic growth, expand trade and investment. Under the background of The Belt and Road construction putting forward by China, deepen economic and trade cooperation will happen between China and Russia. In 2016, total volume of import and export trade between China and Russia reached to 69 billion 525 million dollars, increase of 2.2\% year-on-year growth.

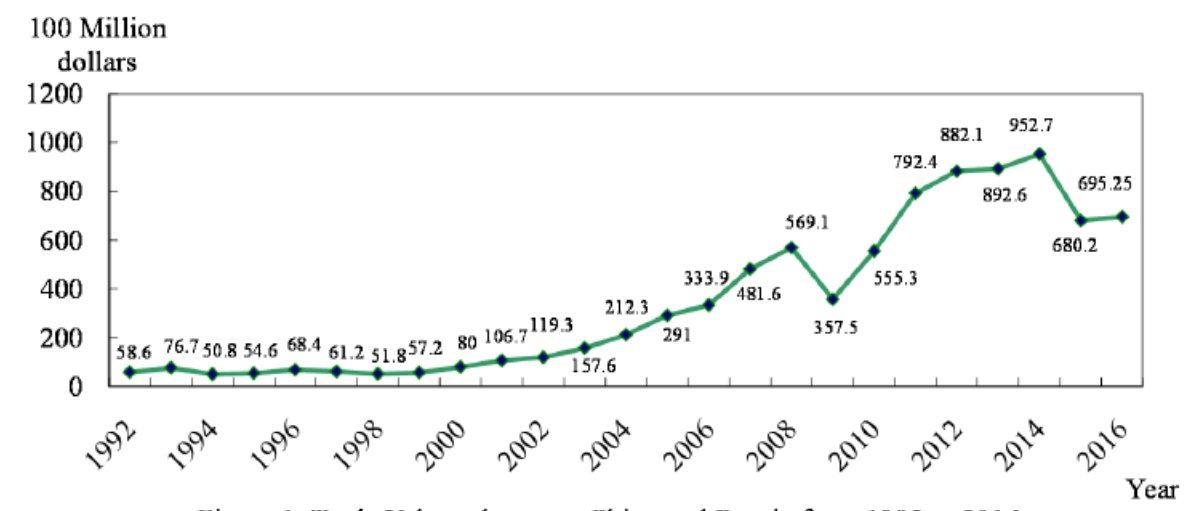

Figure 1. Trade Volume between China and Russia from 1992 to 2016

Figure1. Trade Volume between China and Russia from1992 to 2016 Data source: China Statistical Yearbook.

\section{The Economic Structure is Highly Complementary.}

Since the beginning of 1990s, between China and Russia from the primitive barter trade development to mature trade today, economic complementarity is the leading factor which runs through, is a great force to guide the sustainable development of trade between the two countries.

Complementary natural resources. China and Russia are both big resource countries, and there are many kinds of natural resources. Chinese natural resources has the characteristics of large quantity, variety, has many advantages, but because of the large population, rapid growth rate, the per capita consumption of resources is little, with the pace of modernization deepening, the problem of shortage of resources become more and more prominent, the contradiction between supply and demand is gradually increased. Compared to China, Russia's resource reserves are more abundant, especially with more abundant oil and natural gas. Russia is one of the most important oil importing countries to China. In 2016 Russia replaced Saudi Arabia and became China's largest oil supplier for the first time. China's oil imported from Russia grew by nearly 1/4, to 1 million 50 thousand barrels per day, an increase of nearly 910 thousand barrels per day compared with 2015.

Complementary labor resources. Russia is the biggest country in the world, an area of 17 million 98 thousand and 200 square kilometers, the total population of 144 million, which belongs to the type of typical countries with much land and few people, since 2012, Russia is committed to the development of the Far East, but the Far East, which occupies 3/4 of Russia's land area, is home to only 1/4 of the country's population. Severing shortage of labor resources has become an important factor restricting the development of the Russian Far East, meanwhile, China population has exceeded 1 billion 400 million, rich in labor resources, and Russia's Far East is adjacent to Northeast China, a large number of China workers, engaged in forestry construction and other fields of work in Russia's Far East, to 
solve the situation of lack of labor resources in Russia to some extent, has injected vitality for Russia's economic development.

Complementary technology. Russia is developing at a faster pace in areas with high technology, with innovative consciousness and strong ability in the field of advanced science, can represent the international first-class level in the military, petrochemical, aerospace and other fields, the technical equipment is widely used in Chinese market. And China's home appliance manufacturing, food processing, building materials production, communications and other technologies also have a leading level, can make up for the lack of civil technology in russia. Cooperation between China and Russia in the field of technology will enable economic win-win situation.

Complementary economic structure. Chinese has advantages in the development of light industry, and relying on the vast potential market and huge productivity, is the leader in the field of the light industry. Because of its rich resources and scientific and technological strength, Russia focuses on the development of heavy industries. The complementarity of the two countries in terms of economic structure provides a strong guarantee for economic and trade cooperation between the two countries.

Table 1. Commodity Structure Change of Import and Export between China and Russian (Take 2002, 2006, 2009 and 2014 as examples)

\begin{tabular}{|c|c|c|}
\hline Year & Russia's main exports to China & China's main exports to Russia \\
\hline \multirow{2}{*}{2002} & $\begin{array}{c}\text { Petroleum products; petroleum } \\
\text { products and raw materials; } \\
\text { wood and wood products; other } \\
\text { transport equipment; steels. }\end{array}$ & $\begin{array}{c}\text { Clothing products; shoes and boots; } \\
\text { light industrial products; } \\
\text { miscellaneous products; } \\
\text { telecommunications and equipment } \\
\text { products; textiles, fabrics, products }\end{array}$ \\
\hline \multirow{2}{*}{2006} & $\begin{array}{c}\text { Minerals; steels; wood and wood } \\
\text { products; fertilizers; organic } \\
\text { chemicals. }\end{array}$ & $\begin{array}{c}\text { Mechanical and electrical Products; } \\
\text { nuclear reactors; shoes and boots and } \\
\text { other light industrial products; toys and } \\
\text { sporting goods; plastics and products. }\end{array}$ \\
\hline $\begin{array}{c}\text { Mineral products; wood and } \\
\text { mineod products; base metal } \\
\text { products; } \text { plectromechanical } \\
\text { products. }\end{array}$ & $\begin{array}{c}\text { Mechanical and electrical products; } \\
\text { textiles and raw materials; light } \\
\text { industrial products such as shoes, boots } \\
\text { and umbrellas; base metal minerals and } \\
\text { products; furniture, toy products and } \\
\text { other products. }\end{array}$ \\
\hline \multirow{2}{*}{2014} & $\begin{array}{c}\text { Mineral products; wood and } \\
\text { wood products; chemical } \\
\text { products; electromechanical } \\
\text { products; animal products and } \\
\text { products. }\end{array}$ & $\begin{array}{c}\text { Mechanical and electrical products; } \\
\text { textiles and their raw materials; base } \\
\text { metal products and products; furniture, } \\
\text { toys and miscellaneous products; } \\
\text { plastics and products. }\end{array}$ \\
\hline
\end{tabular}

Data source: Ministry of commerce country report - Russia

\section{Barriers for Establishing Sino Russian Free Trade Area}

\section{The Trade Regime and System are Imperfect.}

China and Russia are confused in terms of the trade system, lacking of relatively sound and perfect performance mechanism, the vicious competition among enterprises has also seriously damaged the normal economic and trade development of China and Russia. Because of the imperfect trade regime, the trade system between the two countries is imperfect, mainly in customs and trade dispute settlement. Russian Customs personnel quality is low, the work efficiency is low, and the clearance is extremely complex, poor infrastructure, leading to corruption in vogue, China's export goods are 
often stranded in Russian customs. In addition, in the process of rapid development between China and Russia, inevitably there will be a series of trade disputes and trade disputes, and because both countries lack of reasonable and fair dispute settlement mechanism, These trade disputes are usually not well resolved, leading The trade relations between China and Russia gradually deteriorated, hinder the development of bilateral economic and trade relations between the two countries.

\section{The Existence of "China Threat Theory".}

China is an ancient country with a long history and has been adhering to the Confucian culture, and Russia has a history of seven thousand years. The people of the two countries have great differences in their religious beliefs, ways of thinking and values. In addition, some interest groups in Russia and the media are full of "China Threat Theory", saying that China is more effective than Europe and America in its system and development model and China will take the place of them. Some western countries have been advocating, so that the Russian domestic enterprises will believe in the "China Threat Theory" argument, some Russian companies are reluctant to cooperate with China, even China's import of timber from Russia would be considered a plundering of Russian resources.

\section{Quality Problems of China's Export Products.}

As early as 1950s to 90s, China's exports to Russia were high quality and inexpensive. Chinese goods are described as "fashion Representatives" by Russian consumers. But in recent years, due to the lack of standardized management of trade between China and Russia, some Chinese enterprises lack honesty consciousness, exporting a large number of counterfeit and shoddy products to Russia, the consumers are seriously dissatisfied for it.

\section{Conclusion}

The construction of Sino Russian free trade area is a long, complex process, during the long process there will also appear of the barriers in all aspects, but China and Russia leaders attach great importance to continue to deepen economic and trade cooperation, and to promote the political support to the firm, the two countries will work together to build the bilateral free trade area and work. However, the leaders of China and Russia attach great importance to the deepening of economic and trade cooperation, give political support and firmly push forward, and the two countries will work together to build a Sino Russian free trade area. On the base of "The Belt and Road" initiative, China and Russia should make efforts to change the mode of cooperation, improve the quality of product cooperation, expand the scope of mutual investment, and find new economic growth points. China and Russia are friendly neighbors linked to land, it is necessary for sustained economic growth to establish Sino Russian free trade area. The trade relations between China and Russia also have considerable room for development and need to explore together.

\section{References}

[1] Jeanne L. Wilson. The Eurasian Economic Union and China's silk road: implications for the Russian-Chinese relationship. 2016(sup1): 113-132

[2] Hai-Bin Wang, Jian-Jun Hong, The Eurasian Economic Union and Its World Influence. 2015(5): 105-121

[3] Yu-Rong Chen. Silk Road Economic Belt-Call of the times. 2014(1): 9-12

[4] C. Vladlen Biryukov. "Silk Road" and Eurasian Integration-Prospects for the Combination of the Two Major Strategic Projects. 2015(6): 31-57

[5] Xue Chen. Feasibility study of China-Russia free trade area. Qingdao, 2014: 6

[6] John D Schulz. "New Silk Road" opportunities await multinationals in new ground route between Europe, China. 2016(6): 12-13 
[7] Jeanne L. Wilson. The Eurasian Economic Union and China's silk road: implications for the Russia-Chinese relationship. 2016(9): 113-132 